Riddles of Belonging 
This page intentionally left blank 


\section{Riddles of Belonging}

INDIA IN TRANSLATION AND

OTHER TALES OF POSSESSION

Christi A. Merrill

F O R DHA M U N IVERSITY PRES S

N E W Y O R $\quad 2$ O O 9 
Copyright () 2009 Fordham University Press

All rights reserved. No part of this publication may be reproduced, stored in a retrieval system, or transmitted in any form or by any means-electronic, mechanical, photocopy, recording, or any other-except for brief quotations in printed reviews, without the prior permission of the publisher.

Fordham University Press has no responsibility for the persistence or accuracy of URLs for external or third-party internet websites referred to in this publication and does not guarantee that any content on such websites is, or will remain, accurate or appropriate.

Library of Congress Cataloging-in-Publication Data

Merrill, Christi A.

Riddles of belonging : India in translation and other tales of possession / Christi A. Merrill. — Ist ed.

p. cm.

Includes bibliographical references and index.

ISBN 978-o-8232-2955-o (cloth : alk. paper)

I. Indic literature-Translations-History and criticism.

2. Folk literature, Indic-Translations-History and criticism.

3. Detha, Vijayadanna-Translations-History and criticism.

I. Title.

$\mathrm{PK}_{5409 \cdot \mathrm{M}_{47} 2008}$

$891.409-\mathrm{dc} 22$

2008037466

Printed in the United States of America

IO $09 \circ 85432$ I

First edition 
For Dorothy Freeman, whose keen habits of reading and of living have inspired me at every turn, and for her twin sister and my mother, Dolores Miller, who passed away while this book was being completed and whose memory has left its mark on every page. 
This page intentionally left blank 